\title{
Impact of the Peace Agreement on the social determinants of health in Colombia
}

\author{
Impacto do Acordo de Paz nos determinantes sociais da saúde na Colômbia \\ Impacto del Acuerdo de Paz sobre los determinantes sociales de la salud en Colombia
}

Edna Johana Mondragón-Sánchez'
ORCID: 0000-0002-7950-2809
Reinaldo Gutiérrez Barreiro"
ORCID: 0000-0002-1027-9012

Marcos Venícios de Oliveira Lopes" ORCID: 0000-0001-5867-8023

Ana Karina Bezerra Pinheiro" ORCID: 0000-0003-3837-4131

Priscila de Souza Aquino" ORCID: 0000-0003-4976-9817

Patrícia Neyva da Costa Pinheiro" ORCID: 0000-0001-7022-8391

'Universidad del Quindio. Armenia, Quindio, Colombia. "Universidade Federal do Ceará. Fortaleza, Ceará, Brazil.

How to cite this article: Mondragón-Sánchez EJ, Barreiro RG, Lopes MVO, Pinheiro AKB, Aquino PS, Pinheiro PNC. Impact of the Peace Agreement on the social determinants of health in Colombia. Rev Bras Enferm. 2021;74(2):e20200892. https://doi.org/10.1590/0034-7167-2020-0892

\section{Corresponding author:}

Edna Johana Mondragón Sánchez E-mail: ejmondragon@uniquindio.edu.co

EDITOR IN CHIEF: Antonio José de Almeida Filho ASSOCIATE EDITOR: Andrea Bernardes

Submission: 08-21-2020

Approval: $11-13-2020$

\begin{abstract}
Objectives: to analyze the impact of the Colombian Peace Agreement on the structural social determinants of health. Methods: a descriptive, ecological study, based on documentary data from 2008 to 2018. The records of victims, epidemiological indicators, and structural social determinants of health in Colombia were analyzed. Results: there was a correlation between the period in which the Peace Agreement process was developed and the indicators of structural determinants in health with $p<0.05$. With the Poisson regression analysis, the favorable correlations between the peace process and the determinants were confirmed, besides allowing the understanding of the changes in these indicators before the Peace Agreement. Conclusions: the implementation of the peace process has a positive impact on structural social determinants of health, which is observed by the beginning of the decrease of economic, educational, health, and social inequalities and inequities, a fact that offers the possibility of living in peace.

Descriptors: Social Determinants in Health; Violence; Investment; Poverty; Armed Conflicts.
\end{abstract}

\section{RESUMO}

Objetivos: analisar o impacto do Acordo de Paz da Colômbia nos determinantes sociais estruturais da saúde. Métodos: estudo descritivo, ecológico, a partir de dados documentais do período de 2008 a 2018. Analisaram-se os registros de vítimas, indicadores epidemiológicos e determinantes sociais estruturais em saúde da Colômbia. Resultados: correlação entre o período de tempo em que se desenvolveram o processo de Acordo de Paz e os indicadores dos determinantes estruturais em saúde com $\mathrm{p}<0.05$. Com a análise da regressão de Poisson, confirmaram-se as correlações favoráveis entre o processo de paz e os mencionados determinantes, além de permitir explicar as mudanças nesses indicadores perante o Acordo de Paz. Conclusões: a implementação do processo de paz tem impacto favorável nos determinantes sociais estruturais da saúde, o que reflete no início da redução das desigualdades e iniquidades econômicas, educacionais, de saúde e sociais, fato que oferece a possibilidade de viver em paz.

Descritores: Determinantes Sociais em Saúde; Violência; Investimento; Pobreza; Conflitos Armados.

\section{RESUMEN}

Objetivos: analizar el impacto del Acuerdo de Paz de Colombia en los determinantes sociales estructurales de la salud. Métodos: estudio descriptivo, ecológico, a partir de datos documentales del periodo de 2008 a 2018. Se analizaron los registros de víctimas, indicadores epidemiológicos y determinantes sociales estructurales en salud de Colombia. Resultados: correlación entre el periodo de tiempo en que se desarrollaron el proceso del Acuerdo de Paz y los indicadores de los determinantes estructurales en salud con $p<0,05$. Mediante el análisis de regresión de Poisson, se confirmaron las correlaciones favorables entre el proceso de paz y los determinantes mencionados, además de permitir explicar los cambios en dichos indicadores frente al Acuerdo de Paz. Conclusiones: la implementación del proceso de paz impacta favorablemente en los determinantes sociales estructurales de la salud, lo que refleja en el inicio la reducción de las desigualdades e inequidades económicas, educacionales, de salud y sociales, hecho que ofrece la posibilidad de vivir en paz.

Descriptores: Determinantes Sociales en Salud; Violencia; Inversión; Pobreza; Conflictos Armados. 


\section{INTRODUCTION}

War and armed conflicts, caused by political and economic interests, engender major public health problems, not only because of direct deaths and disabilities, but also due to the magnitude of the indirect effects on the civilian population, especially on the health and well-being of individuals, families and communities ${ }^{(1-2)}$.

Colombia's armed conflict, experienced for more than five decades, is the result of disagreements in political, ideological and economic interests that have led to a lengthy sequence of military confrontations and terrorist actions between the Colombian State and different guerrilla organizations since 1960, aggravated by the outbreak and expansion of drug trafficking in the early 1970 and by paramilitary organizations that appeared in the early $1980 \mathrm{~s}^{(2)}$.

The effect of the Colombian war conflict has negative effects on the population's health, not only on the indicators of different ways of violence, such as homicides, missing persons, forced displacements and kidnappings, but also affect the overall health and quality of life for Colombians, since the actions of the protagonists of the conflict range from armed confrontations to the interruption, denial or manipulation of health services, interfering, intimidating and preventing health professionals from carrying out activities ${ }^{(2-3)}$. Thus, it is evident that the Colombian population has suffered high human, economic, demographic, and social damage ${ }^{(4-5)}$.

In this scenario, the Colombian State has pursued the search for peace at different times, since this is a constitutional right of all citizens and a duty of the President of the Republic of Colombia ${ }^{(6)}$. However, after several attempts to negotiate with the guerrillas and without achieving any success ${ }^{(7)}$, in 2012 , a new attempt was made to reach peace with the guerrilla named Revolutionary Armed Forces of Colombia - People's Army (FARC- EP).

Furthermore, a cooperation team was established to talk over peace agreements, a process that took nearly four years of negotiations, a period in which there were several demonstrations and signs of the will to peace and to end violence to solve political disagreements, for example, the bilateral cessation of hostilities and the armed confrontation between the parties involved, a sample of the intention to seek a negotiated solution to the conflict in Colombia. These peaceful actions have affected the quality of life of the civilian population, which has historically been affected by decades of armed conflict. The negotiations were successfully concluded in $2016^{(8)}$, representing an advance for Colombians and humanity.

As a result of the negotiations, the Peace Agreement was obtained, composed of six points: Policy on integral agrarian development; Political Participation; Victims of armed conflict; End of the conflict; Solution to the Illicit Drugs problem; and Implementation and verification. The negotiators aimed to reach a final agreement that would end the direct violence (an evident consequence of the conflict), as well as reach the structural causes of the armed conflict ${ }^{(9-10)}$. However, the Peace Agreement did not consist exclusively of ending the war in military and armed terms, on the contrary, it has articulated commitments that seek to balance social inequalities to assure peace, especially in the health sectors, economy, education, work and Colombians' income ${ }^{(8-9)}$.
Health and peace are interconnected and interdependent concepts in the lives of people and society, also they have different meanings and implications in the individual and collective fields ${ }^{(4)}$. Both concepts depend on the balance of all sectors (economic, social, protection, labor, among others) for constant construction and functioning, therefore health, as well as peace, is influenced by external factors or conditions ${ }^{(3-5)}$. The set of conditions in which people are born, live, grow, work and age are called Social Determinants of Health (SDH), a term that summarizes the social, economic, political, cultural and environmental determinants that influence the health of members of a society ${ }^{(11)}$.

The Conceptual Framework of Social Determinants of Health (CSDH), in turn, is an analysis of the set of factors that characterize the particularities of individuals and that reflect their insertion in time-space, constitutes a complex network of factors that threaten, promote, or protect the health, they can be grouped into categories or layers, which facilitates the selection of appropriate interventions and the formulation of health policies ${ }^{(11)}$.

The most important determinants ${ }^{(12)}$ are those that stratify society (structural determinants), such as income distribution, prejudice (for example, based on gender, class, ethnicity, disability, or sexual orientation) and the existence of armed conflicts due to disagreements in political or governance structures, reinforcing rather than reducing inequities related to economic power. Thus, war is a highly relevant factor for public health and the creation of health inequalities, not only because of the resources involved in the armed conflict, which means a cutback in social investments but also because of the direct and indirect damage they cause in a population. In this context, the impact of war on the structural mechanisms that influence the social position occupied by individuals is the most relevant cause of health inequities. The discrepancies, due to these mechanisms, shape the health of individuals through intermediate determinants, such as housing conditions and psychosocial aspects, behavioral and biological factors, besides the health system itself $f^{(11-13)}$.

\section{OBJECTIVES}

To analyze the impact of the Colombian Peace Agreement on the structural social determinants of health.

\section{METHODS}

\section{Ethical aspects}

The present study respected the recommendations of Resolution $466 / 2012$ on research with human beings ${ }^{(14)}$. Because it is a documentary study, the units of analysis were information and data, not people, and the study was considered to be of low risk, according to the $11^{\text {th }}$ article of Resolution 008430, of October $4^{\text {th }}, 1993$, of the Republic of Colombia ${ }^{(15)}$, and by Resolution no. 510/2016 of the National Health Council, this study was not registered in the Research Ethics Committee (CEP)/National Research Ethics Committee (CONEP) system. 


\section{Type of study, location, period, and sample}

A descriptive, ecological study was carried out, based on documentary data from 2008 to 2018. The data evaluated relate to epidemiological indicators reported in the attempt, negotiation and implementation of the peace process and structural social determinants in health (SDH), according to the Conceptual Framework for Social Determinants of Health $(\mathrm{CSDH})^{(13)}$. To guide the methodology of the present study, the STROBE instrument was used.

\section{Study protocol}

Data recorded on the platform of the National Administrative Department of Statistics (DANE) and the Unit were retrieved for comprehensive care and restitution to victims of the Republic of Colombia. The Peace Agreement was analyzed as a process that involves the period before the attempts at reconciliation between the government and the FARC-EP. However, the Peace Agreement process, which was assessed as the period that elapsed through the process that comprises the beginning and establishment of negotiations, the final agreement, signature and entry into force, and the years after the signing of peace treaties, specifically between years 2008 and $2018^{(13)}$. The negotiations for the Peace Agreement were a long process, and this time interval was evaluated to have a comparative analysis of the situations that preceded the peace talks, the time during the negotiations and after the signing of the agreement, thus being able to assess the impact of the Colombian Peace Agreement on the CSDH.

The CSDH were analyzed subdivided into the layers described below: Governance: victim index and event index; Macroeconomic policies; Gross Domestic Product (GDP): investment in health, education and protection; Social policies: monetary poverty index, extreme poverty index and unemployment index; Public policies: health coverage and illiteracy rate ${ }^{(12)}$.

\section{Analysis of results and statistics}

The variables were analyzed and were calculated using descriptive statistics, mean, median, variance, and standard deviation. Associations between structural health determinants and the peace process were also verified using Pearson's correlation test and Spearman's rho, considering statistical significance when $p<0.05$. Furthermore, univariate models of Poisson Regression were adjusted for the variables of interest and measures of relative risk with the respective $95 \%$ confidence intervals are presented. This analysis was carried out to verify changes in health indicators (structural health determinants) (16-17) over time, including the periods immediately before and after the Peace Agreement.

\section{RESULTS}

Table 1 presents descriptive statistics and analysis of the correlation of structural social determinants in health. In the governance layer, the violence events indicator showed a negative correlation, with $\mathrm{p}<0.05$, however, during the analyzed time, the violence events decreased. On the other hand, in the macroeconomic policy layer, as time went by, a positive correlation was found with investment in health, with $p<0.05$, which means that investment in health increased in that period of time. In the social policy layer, negative correlations were found in the indicators of monetary poverty, extreme poverty and unemployment, $p<0.05$. However, at that time, the indicators decreased. Regarding the public policy layer, the health coverage indicator was not statistically significant, but it was close to $p<0.05$, indicating a correlation that points to a possible association over a longer period of time, however, illiteracy showed a negative correlation, with $\mathrm{p}<0.05$.

Table 1 - Descriptive Statistics and Correlation Analysis of Structural Social Determinants in Health, Colombia, 2008-2018

\begin{tabular}{|c|c|c|c|c|c|c|}
\hline Variables & Average & Md & IQR & SD & $\begin{array}{c}\text { W } \\
p \text { value }^{a}\end{array}$ & $\begin{array}{c}\text { Correlation } \\
\text { Analysis } \\
p \text { value } \\
(95 \% \mathrm{Cl})\end{array}$ \\
\hline \multicolumn{7}{|l|}{ Governance } \\
\hline Victims & 426.16 & 488.38 & 301.36 & 182.70 & $\begin{array}{c}0.890 \\
p=0.143\end{array}$ & $\begin{array}{c}0.283^{\mathrm{b}} \\
(-0.7540 .381) \\
p=0.398\end{array}$ \\
\hline Events Violence & 580.97 & 622.5 & 257.98 & 232.76 & $\begin{array}{c}0.941 \\
p=0.537\end{array}$ & $\begin{array}{c}-0.789 \\
(-0.942-0.360) \\
p=0.003^{b}\end{array}$ \\
\hline \multicolumn{7}{|l|}{ Macroeconomic policies } \\
\hline $\mathrm{PIB}$ & 34.6 & 2.6 & 2.3 & 1.93 & $\begin{array}{c}0.852 \\
p=0.046\end{array}$ & $\begin{array}{c}-0.369 \\
(0.570-0.977) \\
p=0.264^{c}\end{array}$ \\
\hline Health Investment & 72.33 & 72.34 & 5.03 & 2.85 & $\begin{array}{c}0.912 \\
p=0.299\end{array}$ & $\begin{array}{c}0.729 \\
(0.1840 .931) \\
p=0.016^{\mathrm{b}}\end{array}$ \\
\hline Education Investment & 15.75 & 15.69 & 0.74 & 0.65 & $\begin{array}{c}0.990 \\
p=0.997\end{array}$ & $\begin{array}{c}0.051 \\
(-0.5970 .659) \\
p=0.887^{\mathrm{b}}\end{array}$ \\
\hline Protection Investment & 11.39 & 11.27 & 0.78 & 0.81 & $\begin{array}{c}0.911 \\
p=0.288\end{array}$ & $\begin{array}{c}-0.457 \\
(-0.8440 .241) \\
p=0.183^{b}\end{array}$ \\
\hline \multicolumn{7}{|l|}{ Social policies } \\
\hline Monetary poverty & 32.28 & 30.6 & 7.75 & 5.46 & $\begin{array}{c}0.873 \\
p=0.086\end{array}$ & $\begin{array}{c}-0.954 \\
(-0.988-0.828) \\
p<0.001^{\mathrm{b}}\end{array}$ \\
\hline Extreme poverty & 10.20 & 9.1 & 3.45 & 3.02 & $\begin{array}{c}0.878 \\
p=0.099\end{array}$ & $\begin{array}{c}-0.928 \\
(-0.981-0.742) \\
p<0.001 \mathrm{~b}\end{array}$ \\
\hline Unemployment & 10.2 & 9.7 & 1.75 & 1.12 & $\begin{array}{c}0.900 \\
p=0.184\end{array}$ & $\begin{array}{c}-0.842 \\
(-0.958-0.489) \\
p=0.001^{\mathrm{b}}\end{array}$ \\
\hline \multicolumn{7}{|l|}{ Public policy } \\
\hline Health coverage & 94.83 & 95.66 & 2.27 & 2.32 & $\begin{array}{c}0.875 \\
p=0.090\end{array}$ & $\begin{array}{c}0.593 \\
(-0.0100 .879) \\
p=0.054^{\mathrm{b}}\end{array}$ \\
\hline Illiteracy & 17.52 & 17.45 & 2.5 & 1.71 & $\begin{array}{c}0.970 \\
p=0.898\end{array}$ & $\begin{array}{c}-0.998 \\
(-0.999-0.989) \\
p<0.001^{\mathrm{b}}\end{array}$ \\
\hline
\end{tabular}


Table 2 - Poisson Regression of Structural Social Determinants in Health, Colombia, 2008-2018

\begin{tabular}{|c|c|c|c|c|c|c|}
\hline Variables & Coef $^{\mathrm{a}}$ & $\mathbf{S E}^{\mathbf{b}}$ & $\mathbf{Z}^{\mathrm{c}}$ & $\begin{array}{c}p \\
\text { value }\end{array}$ & $\mathbf{R R}^{\mathbf{d}}$ & $95 \% \mathrm{Cl}^{\mathrm{e}}$ \\
\hline \multicolumn{7}{|l|}{ Governance } \\
\hline Victims & -0.04 & 0.05 & -0.80 & 0.430 & 1.00 & $0.88 \quad 1.05$ \\
\hline Events Violence & -0.10 & 0.02 & -4.47 & $<0.001$ & 0.90 & 0.870 .95 \\
\hline \multicolumn{7}{|l|}{ Policies macroeconomic } \\
\hline GDP & -0.06 & 0.04 & -1.52 & 0.130 & 0.90 & $0.87 \quad 1.02$ \\
\hline Health Investment & 0.01 & 0.00 & 4.74 & $<0.001$ & 1.00 & 1.011 .01 \\
\hline Education Investment & 0.00 & 0.00 & 0.16 & 0.880 & 1.00 & 0.991 .01 \\
\hline Protection Investment & -0.01 & 0.01 & -1.41 & 0.160 & 1.00 & $0.97 \quad 1.00$ \\
\hline \multicolumn{7}{|c|}{ Social policies } \\
\hline Monetary poverty & -0.05 & 0.00 & -11.69 & $<0.001$ & 0.95 & $0.94 \quad 0.96$ \\
\hline Extreme poverty & -0.08 & 0.01 & -10.39 & $<0.001$ & 0.91 & $0.90 \quad 0.93$ \\
\hline Unemployment & -0.03 & 0.01 & -4.96 & $<0.001$ & 0.97 & 0.960 .98 \\
\hline \multicolumn{7}{|l|}{ Public policy } \\
\hline Health coverage & 0.00 & 0.00 & 2.17 & 0.030 & 1.00 & 1.001 .01 \\
\hline Illiteracy & -0.04 & 0.00 & -105.47 & $7<0.001$ & 0.96 & 0.960 .97 \\
\hline
\end{tabular}

As Table 2 shows the Poisson Regression Model of structural social determinants in health, a trend towards a $10 \%$ drop in the risk of violence events per 100,000 inhabitants was identified (RR $=0.90 ; 95 \% \mathrm{Cl}: 0.87-0,95)$. Also, risk reductions were also identified for the variables monetary poverty $(\mathrm{RR}=0.95 ; 95 \% \mathrm{Cl}: 0.94-0.96)$, extreme poverty $(\mathrm{RR}=0.91 ; 95 \% \mathrm{Cl}: 0.90-0.93)$, unemployment $(\mathrm{RR}=0.97 ; 95 \% \mathrm{Cl}: 0.96-0.98)$ and illiteracy $(\mathrm{RR}=0.96 ; 95 \% \mathrm{Cl}: 0.96$ - 0.97). The investment in health and coverage showed a small tendency to increase, which, although they showed statistical significance $(p<0.001)$, did not influence the relative risk in the studied period.

\section{DISCUSSION}

The results indicated a positive impact on structural health determinants, such as governance, macroeconomic, social, and public policies. This finding showed the benefits of the Peace Agreement in the direct and indirect causes of the inequalities and inequities that affect the well-being of Colombians.

Regarding the governance sphere, the indicator of victims of armed conflict did not correlate with the peace process. It should be clarified that the number of victims showed a trend to decrease up to the year 2017, although the year 2018 presented an increase in the number of victims of violence, since it went from 212 per 100,000 inhabitants, in the year 2017, to 316 per 100,000 inhabitants in $2018^{(18)}$. This indicates that violence continues to exist and affect the Colombian population. Regarding the indicator of violent events, it showed a negative correlation, which means a decrease in the number of violent events after the peace agreements ${ }^{(18)}$.

It is emphasized that the Peace Agreement is a process that requires time to be materialized, besides presenting different challenges to change the Colombian armed conflict and, thus, prevent it from returning more intensely ${ }^{(13)}$, as happened with the peace process between the Colombian government and the paramilitary groups between the years 2003 and 2006, which reoccurred in acting, through a new armed figure, known as the Criminal Bands or Bacrim ${ }^{(19)}$.
Regarding the macroeconomic policy sphere, there was a positive correlation with investment in health ${ }^{(4)}$, which means that the peace process, as well as the end of the armed conflict, had a positive impact on the health sector through the provision of greater resources to guarantee the well-being of the population. However, it is noteworthy that investment in the sectors of education, protection and GDP behavior has not shown significant results in the face of the peace process. That may be due to macroeconomic indicators ${ }^{(5)}$ which need more time to show the changes and substantial impacts that benefit Colombian society.

It is worth mentioning that the Peace Agreement has reached these topics to reduce economic and social inequalities and inequities, which are necessary to guarantee the transformation into a culture of peace ${ }^{(20)}$. Likewise, financial aid and cooperation from the international community (United Nations Fund, World Bank and European Union Fund) ${ }^{(21)}$ are expected to have a positive impact on the country's economic growth and GDP to increase investments in the social sectors and, in this way, power the impact of macroeconomic determinants ${ }^{(22)}$.

In the social policy sphere, the indicators of monetary poverty, extreme poverty and unemployment ${ }^{(23)}$ showed a negative correlation with the peace process, which reveals a positive impact in reducing the number of people in the poverty and unemployment range. This reflects in greater purchasing power and better quality of life for the population ${ }^{(24)}$, emphasizing the importance of improving the previous indicators, since the unequal distribution of wealth, resulting from the nation's resources, causes violent conflicts and resentments generated by poor management and government policies that prevent many sectors from benefiting from these resources ${ }^{(25)}$.

Finally, in the public policy sphere, the health coverage indicator did not show a statistically significant correlation, however it achieved a $\mathrm{p}=0.054$, which shows evidence of correlation, this means a high probability of presenting a positive correlation with a longer period, since it went from $90.29 \%$ in 2008 to $94.96 \%$ in $2018^{(26)}$. With the peace process and the end of the conflict, it is expected to increase health coverage for the population, specifically that found in the old conflict zones ${ }^{(2,4)}$. The illiteracy indicator showed a negative correlation, which indicates a positive impact, showing a significant advance in the growth in the number of people who knew how to read and write during the analyzed period. In this sense, the greatest assignment of public policies must be to raise a discussion in the search for innovative responses, which meet the determinants and needs of the health and education division, to guarantee these rights to the Colombian population $^{(4)}$. In the Poisson regression, the positive correlations between the peace process and the structural social determinants in health are confirmed, specifically in the lessening of risk in the indicators of events of violence, monetary poverty, extreme poverty, unemployment, and illiteracy. Even so, the regression analysis allows us to identify the beginning of an upward trend in investment and health coverage, although these last results have shown statistical significance, they did not have any influence on the relative risk in the studied period, since the increases in investment and interventions to increase health coverage are a process that requires a longer time to be implemented. Thus, these results allow an analysis of the prediction of the possible 
Impact of the Peace Agreement on the social determinants of health in Colombia Mondragón-Sánchez EJ, Barreiro RG, Lopes MVO, Pinheiro AKB, Aquino PS, Pinheiro PNC.

positive impact of the implementation of the peace process and, thus, clarify the changes in the long term in these indicators that benefit the Colombian population.

From this analysis, the relevance of continuing with the implementation of the peace process in the most challenging stage that corresponds to the post-conflict is justified, however it is necessary that all the protagonists of the conflict, government entities, victims, as well as society representatives, continue to work to solve negative conditions, whether economic, social, educational and health, to reduce inequalities and inequities, which are the structural causes of violence in Colombia ${ }^{(4,7)}$, and thus prevent the failure of these negotiations, as was the case with the peace processes in Guatemala and El Salvador ${ }^{(27)}$.

\section{Study limitations}

As study limitations there is the difficulty to access the whole data that was intended to be analyzed at the beginning of the research. Also, for the health, education and protection investment indicators, the information for 2018 was missing, in the same way, in the percentage of illiteracy, the information for the years 2008, 2009 and 2018 are not included. However, these indicators were analyzed according to the available information. Regarding the time considered for the analyzes, it was not possible to infer the correlations in all the variables analyzed, which is why it is recommended to carry out new studies with longer analysis time to confirm the results of this research.

\section{Study contribution}

The Peace Agreement had a positive impact on social determinants of health, which directly affects the state of health and well-being of citizens, but it should not be understood only as a peaceful mechanism for resolving one of the most common armed conflicts of Latin America, but also as an achievement for society. However, peace is achieved not only with negotiation, but with the commitment of all those involved in ensuring compliance, in accordance with an agreement to achieve the total success that characterizes substantial changes in the living conditions of Colombians and, thus, the real possibility of living in a peaceful society.

\section{CONCLUSIONS}

The implementation of the peace process has a positive impact on structural social determinants of health, which is observed by the beginning of the decrease of economic, educational, health, and social inequalities and inequities, a fact that offers the possibility of living in peace.

\section{REFERENCES}

1. Ugalde A, Richards PL. Health consequences of war and political violence. In: Kurtz LR. Encyclopedia of Violence, Peace, and Conflict, vol. 1. Academic Press; 2010. p.923-33.

2. Franco S, Suarez CM, Naranjo CB, Báez LC, Rozo P. The effects of the armed conflict on the life and health in Colombia. Ciênc Saúde Coletiva 2006;11(2):349-61.

3. García ALP. En estos tiempos de guerra: enfermeras ante los conflictos internacionales. Index Enferm [Internet]. 2006[cited 2020 Jul 06];15(54):53-5. Available from: http://scielo.isciii.es/scielo.php?script=sci_arttext\&pid=S1132-12962006000200011

4. Franco S. Editorial Salud para la paz y paz para la salud. Rev Gerenc Polit Salud [Internet]. 2015[cited 2020 Jul 06];14(29):5-8. Available from: http://www.scielo.org.co/pdf/rgps/v14n29/v14n29a01.pdf

5. Vargas Pulido W, Godoy Estrella E. Impacto del gasto de la defensa en el crecimiento económico de Colombia en los últimos veinte años. Rev Cient Gen José María Córdova. 2013;11(11):227. https://doi.org/10.21830/19006586.212

6. República de Colombia (CO). Constitución Política de Colombia de 1991. Colombia: Senado; 1991.

7. Orlando Melo J. Resumen del Acuerdo de Paz. Rev Econ Instit 2016;18(35):319-37. https://doi.org/10.18601/01245996.v18n35.19

8. Moreno Millán F. El concepto de paz en la constitución política de Colombia de 1991: reconstrucción dialéctica de su significado a partir de la jurisprudencia de la corte constitucional. RDUCN 2014;21(2):305-46. https://doi.org/10.4067/S0718-97532014000200009

9. Valencia Gutiérrez A. La Violencia en Colombia de M. Guzmán, O. Fals y E. Umaña y las trasgresiones al Frente Nacional. Rev Colomb Soc [Internet]. 2012[cited 2020 Jul 06];35(2):15-33. Available from: https://revistas.unal.edu.co/index.php/recs/article/view/37195

10. González Munoz CA. Diálogos de paz Gobierno-FARC-EP y las oportunidades para la paz en Colombia. Estud Polít [Internet]. 2015[cited $2020 \mathrm{Jul}$ 06];46:243-61. Available from: http://www.scielo.org.co/pdf/espo/n46/n46a13.pdf

11. World Health Organization (WHO). A conceptual framework for action on the social determinants of health: debates, policy \& practice, case studies. Geneva:WHO; 2010.

12. Costa MIF, Viana TRF, Pinheiro PNC, Cardoso MVLML, Barbosa LP, Luna IT. Social determinants of health and vulnerabilities to sexually transmitted infections in adolescents. Rev Bras Enferm. 2019;72(6):1595-601. https://doi.org/ 10.1590/0034-7167-2018-0726

13. Calderón RJ Etapas del conflicto armado en Colombia: hacia el posconflicto. Latinoamérica [Internet]. 2016[cited 2020 Jul 06];62:227-57. Available from: http://www.scielo.org.mx/pdf/latinoam/n62/1665-8574-latinoam-62-00227.pdf

14. Ministério da Saúde (BR). Conselho nacional de Saúde. Comissão Nacional de ética em Pesquisa. Resolução n 466 , de 12 de dezembro de 2012. Aprova as diretrizes e normas regulamentadoras de pesquisa envolvendo seres humanos. Brasília (DF): Ministério da Saúde; 2012. 
15. Ministerio de la Salud (CO). Resolución 8.430, de 4 de octubre de 1993. Por la cual se estableces las normas científicas, técnicas y administrativas para la investigación en salud. Santa Fe Bogotá:Título II, Capitulo 1, Articulo 11.

16. Cardona Madariaga DF, González Rodríguez JL, Rivera Lozano M, Cárdenas Vallejo EH. Aplicación de la regresión lineal en un problema de pobreza. Interaccion. 2014;12:73-84. https://doi.org/10.18041/1657-7531/interaccion.0.2315

17. Navarrete MPCD. Aplicación del método de regresión lineal en el análisis de los determinantes de la inversión extranjera en Colombia. Colombia: FCE; 2011.

18. Governo de Colombia (CO). Registro Único de Víctimas (RUV). Unidad para las Víctimas. Colombia: RUV; 2018.

19. Organización de Estados Americanos. Secretaría General. Octavo informe trimestral del Secretario General al Consejo Permanente sobre la Misión de Apoyo al Proceso de Paz en Colombia (MAPP/OEA). Colombia: MAPP; 2007.

20. Marín-Cortés A, Quintero JJ. Confianza en el proceso de paz en Colombia en Twitter. Rev Mex Soc [Internet]. 2018[cited 2020 Jul 06];80(1):115-37. Available from: http://www.scielo.org.mx/pdf/rms/v80n1/0188-2503-rms-80-01-00115.pdf

21. Henriques MB. Preparar el post-conflicto en Colombia desde los programas de desarrollo y paz: retos y lecciones aprendidas para la cooperación internacional y las empresas. Rev Relac Int Estrateg Segur. 2014;9(1):179-97. https://doi.org/10.18359/ries.56

22. Pellegrini Filho A. Conferência Mundial sobre Determinantes Sociais da Saúde. Cad Saúde Pública. 2011;27(11):2080-2. https://doi. org/10.1590/S0102-311X2011001100001

23. Departamento Administrativo Nacional de Estadísticas (CO). Gran Encuesta Integrada de Hogares: información general. Colombia: DANE; 2018.

24. Departamento Administrativo Nacional de Estadísticas (CO). Encuesta nacional de calidad de vida (ECV). Colombia: DANE; 2018.

25. Yaffe L. Conflicto armado en Colombia: análisis de las causas económicas, sociales e institucionales de la oposición violenta. Rev CS[Internet]. 2011 [cited 2020 Jul 06];8:187-208. Available from: http://www.scielo.org.co/pdf/recs/n8/n8a07.pdf

26. Departamento Administrativo Nacional de Estadísticas (CO). Censo Nacional de Población y Vivienda [Internet]. 2018 [cited 2019 Nov 20]. Available from: https://www.dane.gov.co/index.php/estadisticas-por-tema/demografia-y-poblacion/ censo-nacional-de-poblacion-y-vivenda-2018

27. Anaya Caraballo L, Mogollón Anaya N. El conflicto armado interno colombiano: una mirada socio-jurídica desde la jurisprudencia de la Corte Penal Internacional. Justicia Juris 2016; 12(1):107-17. https://doi.org/10.15665/rj.v12i1.892 